TESG Forum:

Revisiting 'The Changing State of Gentrification'

\title{
Introduction to the Forum: From Third- to Fifth-Wave Gentrification
}

\author{
Forthcoming in: Tijdschrift voor Economische en Sociale Geografie
}

\author{
Manuel B. Aalbers \\ Division of Geography \& Tourism, \\ KU Leuven, the University of Leuven \\ Celestijnenlaan 200E bus 2409 \\ B-3001, Leuven, Belgium \\ manuel.aalbers@kuleuven.be
}

\begin{abstract}
'The Changing State of Gentrification' (2001) by Jason Hackworth and the late Neil Smith is one of the most influential papers ever published in TESG. By introducing three waves, or periods, of practices and patterns of gentrification, it changed the way we think about gentrification. This Introduction to the Forum discusses the three waves introduced by Hackworth and Smith as well as fourth wave introduced by Lees et al. Finally, I will argue that during the global financial crisis we have entered fifth-wave gentrification. Fifth-wave gentrification is the urban materialization of financialized or finance-led capitalism. The state continues to play a leading role during the fifth wave, but is now supplemented-rather than displaced-by finance. It is characterized by the emergence of corporate landlords, highly leveraged housing, platform capitalism (e.g. Airbnb), transnational wealth elites using cities as a 'safe deposit box', and a further 'naturalization' of state-sponsored gentrification.
\end{abstract}

Key words: state-led gentrification, neoliberal urbanism, finance-led capitalism, financialization, corporate landlords, platform capitalism

\section{Introduction}

'The Changing State of Gentrification' (2001) by Jason Hackworth and the late Neil Smith is one of the most influential papers ever published in TESG. The paper changed the way we think about gentrification. Hitherto, discussions had been dominated by production- versus consumption-led debates and the process of gentrification itself had been approached as having different stages (starting with marginal gentrifiers ${ }^{1}$ like artists and students, and ending with full-fledged and later 'super' gentrification ${ }^{2}$ ), but Hackworth and Smith discussed how gentrification was qualitatively different in different decades.

\footnotetext{
${ }^{1}$ Rose (1984).

2 Lees (2003).
} 
Third wave gentrification, sometimes also referred to as state-led or government-sponsored gentrification, was quickly included in discussions of neoliberal urbanism as both paid a great deal of attention to the role of local government in furthering the interests of local elites and developers rather than conceptualizing the local state as primarily interested in welfare. In this wave or phase, gentrification processes, market-led urban public policies and commodification of urban space became 'generalized' as Smith (2002) would later argue. The third wave of gentrification also took gentrification outside the inner city core and into more peripheral urban-and even rural-areas. To me, the concept of third-wave gentrification is more useful than gentrification as a general term; it centres on the role of the (local) state as an instigator, catalyst or sponsor of the socio-spatial restructuring of the city.

The government-sponsored and debt-fuelled gentrification of the late 1990s and early 2000s was at the root of the global financial crisis that started in the US in 2007. Yet, it appears that what we now see in many places, both in those hit hard by the financial crisis and those relatively spared, is the continuation of state-led gentrification. Is this TESG Forum we seek to answer the following questions: What has third wave gentrification meant for urban research and what is its meaning today? How can we use 'wave thinking' to understand contemporary urban processes and policies? Are we still in a third wave or have we entered a fourth or fifth wave-and how are the new waves different from the old one? Our aim in this first TESG Forum is to revisit a classic paper published in TESG and take a moment to reflect on their continued importance of this 'classic' to the field.

In the next section, I will discuss the three waves discussed by Hackworth and Smith as well as Lees, Slater and Wyly's proposition for a fourth wave. In the subsequent section I will argue that we have now entered fifth-wave gentrification. As during earlier waves of gentrification, an economic crisis triggered a mutation in the process of gentrification, which led to the emergence of fifth-wave gentrification in which the process is further generalized. At a more abstract level, fifth-wave gentrification is the urban materialization of financialized or finance-led capitalism. The state continues to play a leading role during the fifth wave, but is now supplemented-rather than displaced-by finance. It is characterized by the emergence of corporate landlords, highly leveraged housing, platform capitalism (e.g. Airbnb), transnational wealth elites using cities as a 'safe deposit box', and a further 'naturalization' of state-sponsored gentrification.

This Introduction to the Forum is followed by three articles and a commentary by Jason Hackworth, the lead author of 'The Changing State of Gentrification'. The editors of TESG have invited four authors that previously have used the idea of the third wave in their work on gentrification in, respectively, North America, East Asia and Western Europe. All four have not simply taken the idea of the third wave at face value, but have used the concept as a starting point to study gentrification rather than as a given, fixed category. We have asked them to discuss the continued usefulness of wave thinking in contemporary gentrification research and debates.

First, Elvin Wyly discusses the critiques that have been launched against 'wave thinking' in gentrification. He argues in favour of such wave thinking; to Wyly gentrification is inseparable from the enduring legacy of evolutionary theory in social science. Shenjing He discusses the meanings and uses of wave thinking to understand gentrification in China. She proposes a 
different periodization, differently defined waves, to understand how the interplay between state, market and society produces gentrification in China. Wouter van Gent and Willem Boterman argue that in gentrification debates, class relations should be more visible vis-à-vis the state. Like He, Van Gent and Boterman adapt the periodization of gentrification to make it fit their case, Amsterdam. They show how Amsterdam was transformed from a radical but largely low-income city into a liberal, middle-class city. Finally, Jason Hackworth responds to the different articles building on or critiquing his taxonomy of gentrification waves. He argues that for Neil Smith and him, gentrification was always about something bigger and should not be separated from broader economic and social processes.

\section{Four Waves of Gentrification}

In their article Hackworth and Smith introduce a periodization of gentrification (see Figure 1). Although they provided examples from New York City to illustrate their argument, they stress that their periodization is based on readings of other cases and has wider applicability: "Specific dates for these phases will undoubtedly vary from place to place, but not so significant as to diminish the influence of broader scale political events on the local experience of gentrification" (Hackworth \& Smith, 2001: 466). In the first wave the dominant discourse on cities is still one of ameliorating urban decline, which in NYC was visible in the form of landlord abandonment and arson. As a result, first-wave gentrification was sporadic, highly localised but also significantly funded by the state.

During the recession of the mid 1970s gentrification mutates. In the resulting second wave federal programmes are scaled back and gentrification takes a more laissez-faire form. At the same time, gentrification expands geographically, covering a larger part of the city, but also internationally. Gentrification is no longer simply a process of class-residential change, but extends into cultural and commercial spheres. The presence of arts and culture, either implicitly or explicitly, often functions as a 'soft factor' attracting new flows of capital into these neighbourhoods. The recession that started with the stock market crash of 1987 and the recession of the early 1990s prompted some to speak of the end of gentrification or of 'degentrification', a myth that was already debunked by Smith in 1995. What happens instead is that gentrification mutates again. 'Third-wave', 'post-recession', 'governmentsponsored' or 'state-led' gentrification is distinct from first- and second wave gentrification in at least four ways:

First, gentrification is expanding both within the inner-city neighbourhoods that it affected during earlier waves and to more remote neighbourhoods beyond the immediate core. Second, restructuring and globalisation in the real estate industry has set a larger context for larger developers becoming more involved in gentrifying neighbourhoods (Logan, 1993; Coakley, 1994; Ball, 1994). While such developers used to be common in the process only after the neighbourhood had been 'tamed' (Zukin, 1982; Ley, 1996), they are now increasingly the first to orchestrate investment. Third, effective resistance to gentrification has declined as the working class is continually displaced from the inner city, and as the most militant antigentrification groups of the 1980s morph into housing service providers. Fourth, and of most relevance to this paper, the state is now more involved in the process than [in] the second wave. (Hackworth \& Smith, 2001: 468)

The concept of state-led gentrification made gentrification research more relevant in both academic and political terms. It was no longer about the small-scale and bottom up initiatives 
Figure 1. Schematic history of gentrification (recessions in grey).

Source: Hackworth \& Smith, 2001

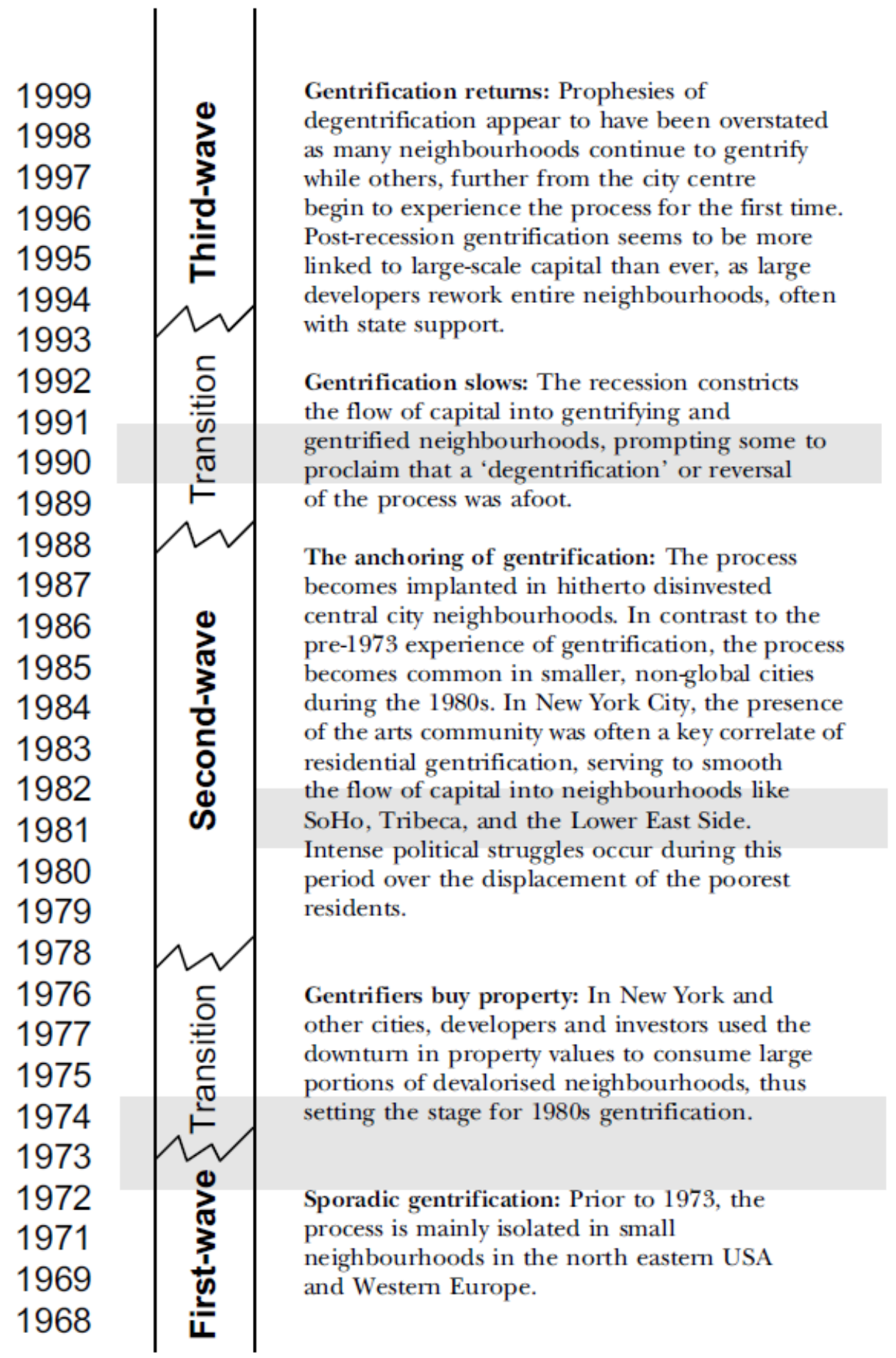

of the first wave. Nor was it simply about developers finding a (new?) way to make money on urban land (second wave). Third-wave gentrification was about how the local and national state use their regulatory and financial powers to enable —and indeed, to boost—profits made by private developers: "state assistance (or some other form of assistance) is increasingly necessary for the process to swallow 'underdeveloped' parcels further from the CBD" (Hackworth \& Smith, 2001: 469). Personally, the heuristic of state-led gentrification has helped me to understand the dynamics of urban change in Amsterdam. In the 'revitalization' of the infamous Bijlmer housing estate, the local and national state were present in many 
different forms and guises. One of the key uses of the state was to make the Bijlmer safe for real estate investment by 'cleaning' the district from undesirable groups like drug users and homeless people (Aalbers, 2011).

Likewise, in the restructuring of Amsterdam's red-light district De Wallen, the local state uses its regulatory and financial power to force a class and image change that makes the area safe for corporate investment (Aalbers \& Deinema, 2012; Deinema \& Aalbers, 2012). Framed as a policy to fight human trafficking, 'Plan 1012' aimed to close most of the brothels on De Wallen and create a "high quality entrance to the city" (City of Amsterdam, 2011: 30). The public presentation of Plan 1012 took place in a hotel that planned to invest EUR120 million in the area and a mid-term evaluation of the plan didn't mention human trafficking once, but bragged about the presence of an Italian wine bar as a sign of the success of the City's interventions. Perhaps the City was aware of what Zukin (1995) and Atkinson (2003), respectively, call 'pacification' and 'domestication' by cappuccino. The City had effectively mobilized a growth coalition or machine, consisting of government agencies, real estate developers, banks, hotel and non-profit housing associations to make De Wallen safe for investment without being able to scale down human trafficking or prostitution, which is simply moved to other, less visible locations (Aalbers \& Deinema, 2012).

Many people have asked the question: is this gentrification? I think the class restructuring of the Bijlmer and De Wallen through government interventions that make these neighbourhoods safe for corporate investment are clear cases of state-led gentrification, i.e. the "subsidized private-market transformation of the urban built environment" (Smith, 2002: 444). The bigger question is: what is the use of the concept of the power of third-wave gentrification? Firstly, Hackworth and Smith have provided us with a periodization of gentrification that can be applied, but also contested or expanded, as we will see in the next section and subsequent articles. It helps us to understand how gentrification is qualitatively different in different periods. Secondly, it helps us to understand international trends in realworld gentrification, as the mutations of gentrification are not limited to NYC or the United States. Although it could be argued gentrification started at a different time in different cities and countries, and that the years in Figure 1 are incorrect for other places, it could also by hypothesized that we are seeing a process of synchronization in which the mutations that result in new phases increasingly take place around the same time (cf. Aalbers, 2015). Thirdly, I see state-led gentrification as a synthesis of the existing gentrification literature with earlier key concepts on urban change, including growth machines (Molotch, 1976), progrowth coalitions (Mollenkopf, 1983) and entrepreneurial urbanism (Harvey, 1989).

The idea of state-led gentrification was quickly picked up in the literatures on gentrification and neoliberal urbanism. The idea of waves itself received a less enthusiastic response and little analytical or theoretical work has been done to expand the thinking about gentrification in terms of periodic phases. In their book, simply titled Gentrification, Lees, Slater and Wyly (2008) are among the few that have tried to theorize subsequent waves of gentrification. They have coined a fourth wave of gentrification that combines "an intensified financialization of housing ... with the consolidation of pro-gentrification politics and polarized urban policies" (Lees et al., 2008: 179) -in other words: third-wave gentrification plus the 'financialization of home' (Aalbers, 2008). Lees and colleagues see this fourth-wave as specific to the US because it "is not readily identifiable outside of the United States" (184). 


\section{Fifth-Wave Gentrification}

It could be argued that fourth-wave gentrification is simply a continuation or even intensification of third-wave gentrification (see also Doucet, 2014). Some countries experienced a crisis in the late 1990s (e.g. the 1997 Asian financial crisis) or early 2000s (e.g. 2001 dot-com crash), which could be considered another period of mutation, but this seems to close to the last transition period. Alternatively, the Asian financial crisis could be considered a delayed transition period to the third wave. Furthermore, the dot-com crash did not result in a deep recession and in hindsight may appear more like a short break during a long period of economic growth. What did change is that the dot-com crash led to a massive switching of capital into real estate, which eventually cumulated in the global financial crisis that started in the United States in 2007 and spread internationally and mutated into several other crises, including the European sovereign debt crisis that started in 2009 and the popping of the Chinese stock market bubble in 2015 (Aalbers, 2015).

These subsequent and linked crises mark a new transition period, which in some countries was-or, still is_characterized by austerity urbanism (Peck, 2012) and temporarily slowed down the state-support of gentrification. This paved to road for a new wave of gentrification: fifth-wave gentrification. At a more abstract level, fifth-wave gentrification is the urban materialization of financialized or finance-led capitalism (e.g. Boyer, 2000). A continuation of the third and fourth waves is that in the fifth wave the state plays a leading role in sponsoring gentrification, but the state's prominent role is now supplemented-rather than displaced-by finance. This is not simply about the financial sector facilitating homeownership through mortgages (as in earlier waves), but also about finance taking a stronger foothold through the rise of corporate landlords (i.e., landlords backed by international capital markets) and platform capitalism (e.g. Airbnb).

In the fifth-wave gentrification becomes further 'generalized' (Smith, 2002) and intensified. The gentrification frontier is not only rolled out to new areas but already gentrifying areas also experience new waves of investment. Local investment remains strong in many areas, but is now supplemented by global investment. Real estate, including housing, is increasingly treated as 'just another asset class' (Van Loon \& Aalbers, 2017; see also Calbet, 2017; Guironnet et al., 2016; Merrifield, 1993). Corporate landlords, backed by capital from Wall Street or the City of London, include Real Estate Investment Trusts (REITs), Real Estate Private Equity (REPE) and other large investment funds that increasingly target not just commercial real estate but also low- and middle-income residential real estate for investment (Beswick et al., 2016; Byrne, 2016 Fields, 2015; 2018; Gotham, 2006; Teresa, 2016; Rouanet \& Halbert; Searle, 2014; Waldron, 2018; Wijburg \& Aalbers, 2017; Wijburg et al., 2018). ${ }^{3}$ Although the effects of REITs, REPE and other investment funds are mixed and can include downgrading of the stock, these funds typically try to maximize rents and benefit from gentrification potential.

International capital also flows into gentrifying and already gentrified neighbourhoods through the investments of transnational wealth elites_or simply the super-rich-and increasingly also upper middle classes into, respectively, 'super-prime' and other classes of residential

\footnotetext{
${ }^{3}$ Slater (2015) also sees the predominance of institutional investors with high return expectations as one of the characteristics of what he names 'planetary rent gaps'.
} 
real estate in elite tourism capitals, prime global cities like London and New York and a range of second-tier global cities such as Vancouver and Amsterdam (Atkinson et al., 2017;

Fernandez et al., 2016; Hay \& Beaverstock, 2016; Ho \& Atkinson, 2017; Ley, 2017; Rogers \& Koh, 2017; Webber \& Burrows, 2015). In many cases, these individual investors, especially the transnational wealth elites, do not buy super-prime real estate to profit from high rents, but rather they use houses and apartments in a select-yet expanding-group of cities as a 'safe deposit box', a place to store their excess capital safely (Fernandez et al., 2016). Such investments have manifold and extensive consequences for the urban fabric, including a disappearing sense of community, diminishing housing affordability and a loss of local economic opportunities. The most immediate consequences of the heightened interest in the top end of the real estate market have been price increases and competition in every segment of the housing market. This has resulted in out-pricing in subsequent price ranges in the already tight housing markets. Sassen (2014) labels the displacements and socioeconomic inequality due to systemic changes in the global economy and unequal access to resources as 'expulsions', a term that points at the irreversibility of these inequalities and displacements.

Platform capitalism, primarily in the form of Airbnb, is another development that channels more capital into specific neighbourhoods, typically those close to the centre or those in 'arty' and 'cultural' areas full of marginal gentrifiers. Dutch bank ING (2016) has concluded that the presence of Airbnb results in price increases, but also that the potential income from Airbnb may call for bigger mortgage loans for apartments and houses with Airbnb-potential. Airbnb has also pushed the 'touristification' of certain neighbourhoods, not only resulting in house price inflation but increasingly also displacement, as Airbnb is often used throughout the year and thereby relegating long-term tenants to other districts (Gant, 2016; Lambea Llop, 2017; Lee, 2017; McNeill, 2016; Mermet, 2017; Sans \& Quaglieri, 2016). Several cities may be trying to regulate Airbnb but so far many Airbnb landlords appear to be bypassing such rules. In Amsterdam-an Airbnb Top 10 city-an increasing number of locals spends the summer camping at the city edge while renting our their properties through Airbnb (Van der Keijl, 2017). Furthermore, large corporations are trying to get into the Airbnb market. Residents in central Amsterdam have received flyers of an investor who is willing to pay 25 per cent over current market prices to acquire apartments that can be rented out through Airbnb (Van der Meijden, 2017). Although this turned out to be a joke, it is a likely future development now that rental housing is increasingly treated as an asset class by international investment funds (Fields, 2018; Wijburg et al. 2018).

Although the global financial crisis has meant a pause in the expansion of mortgage debt, the pause was short and global mortgage debt has been increasing ever since. Many countries in the Global North as well as in the Global South continue to subsidize mortgaged homeownership, often through fiscal measures. Furthermore, the securitization of mortgage loans-the technique that allows mortgages portfolios to be resold to investors and pumps more money into the housing market-has been, and continues to be, rolled out to an increasing number of countries. Fiscal subsidies and securitization do not necessarily result in increasing homeownership rates-in fact, several, mostly Anglophone, countries have seen this rate drop-but mortgage debt has grown exponentially since the crisis as new countries have opened up to more and bigger mortgages loans to an increasing number of households (Fernandez \& Aalbers, 2016; Rolnik, 2013). 
The financialization of housing (Aalbers, 2008; 2016), described by Lees, Slater and Wyly (2008) as a specificity of the US American fourth wave, increasingly is becoming generalized around the globe in fifth wave gentrification. This results in house price inflation across the board, not only in gentrifying neighbourhoods, but it does imply that increasingly larger social groups are excluded from housing in certain locations as prices are simply out of their reach, resulting in a great deal of indirect displacement. As rents broadly tend to follow the developments in house prices, this also puts pressure on rental properties, again not only in gentrifying neighbourhoods, but more so in those areas as there is more potential to raise rents and rent out properties to higher-income groups than those living there previously.

At first sight, the role of the state in all this may appear somewhat ambiguous. On the one hand, many state institutions have pushed mortgaged homeownership, the securitization of mortgages (now also at the international state level ${ }^{4}$ ) and the spread of REITs. On the other hand, local states are increasingly trying to regulate Airbnb as well as international capital going into local housing markets. Overall, however, it appears that the state continues to display many of its third- and fourth-wave features, i.e. state assistance plays an increasingly dominant role in facilitating private investment, not only in inner cities but increasingly also in other parts of the urban region.

The state-support of gentrification is often considered 'natural', as if it is the duty of the state to support private investment. Indeed, in the fifth wave gentrification appears not only generalized but increasingly also naturalized. Local governments may be acting based more on 'potential' than 'need', as Van Gent and Boterman (2019) show for the City of Amsterdam in their contribution to this Forum. Not only entrepreneurial urbanism but also 'New Public Management' ${ }^{5}$ (that suggests government should be run like corporations) has been fully internalized. It remains to be seen if this is part of a wider trend towards the financialization of local government (e.g. Hendrikse, 2015; Peck \& Whiteside, 2016; Van Loon et al., 2018; Weber, 2010). This emerging literature is not just looking into how municipalities are run internally, but also how they sponsor and participate in real estate markets. In some places there appears to be a trend towards the state as not only a sponsor but also a direct agent of gentrification.

An alternative way to read consecutive waves of gentrification-bridging cultural and economic readings of gentrification processes-would be to see gentrification as an important 'urban form of capitalism' that, like capitalism itself, increasingly subsumes urban practices that were once developed as alternatives to urban capitalism. The first-and second waves of gentrification could be characterized by liberal (in the sense of progressive) values, a 'do it yourself' (DIY) mentality and a sense of counterculture, but this often developed into what the French so aptly call BoBo: bourgeois bohemian. The third wave brought attention to arts and culture, but under urban capitalism this was mutated into 'the creative class' (Florida, 2002). Alternative consumption patterns, such as a preference for organic food, popular among many of the new middle classes was also quickly subsumed in new waves of gentrification. Likewise, the promise of the democratization of the (urban) 'sharing economy'

\footnotetext{
${ }^{4}$ See Fernandez \& Aalbers, 2017.

${ }^{5}$ On NPM in local government, see Ward, 2006; Weikart, 2001.
} 
of Airbnb, Uber and other companies is subsumed by a 'cyber-libertarian impulse' (Dahlberg, 2010) that is based on a naïve 'technology solutionism' (Morozov, 2013) under fifth-wave gentrification.

\section{Coda}

Wave thinking in urban research has been criticized for ignoring differences between places. Hackworth and Smith, like others who have advocated a periodization to gentrification have never claimed their waves explain everything or are globally applicable in the sense that they are the same in different places. What they do claim, is that

an explanation that invoked only local differences would not tell us much either. ... [B]ut I think we need to be careful about an illicit slippage between levels of abstraction (universalparticular) and geographical scales of experience (global-local). It has become fashionable to assert privilege of 'local knowledge', to use Geertz's (1983) phrase. The irony, of course is that advocating a certain localism ... can become its own kind of universalist response, threatening a new kind of theoretical stalemate. (Smith, 1995: 124)

Indeed, there are no universally applicable (urban) theories, but there is also no localism that can explain all particularities in a globally connected world. Explanations that suggest all is different and unique are as geographically flat as explanations that suggest that all is universal and the same. Ironically, the latter is often used as a straw-man by the advocates of the former-a straw-man because such claims to universality have long ceased to exist. To understand the particularities of gentrification in different places we need to understand local histories, processes and institutions, but we should be careful to privilege the local and reject the possibility of a 'common trajectory' (Hay, 2004; see also Fernandez \& Aalbers, 2016) a priori. Not all agents of gentrification are locally embedded; policies 'travel'; and Airbnb and REITs are international phenomena. This does not imply their impact is the same everywhere. Policies mutate and agents adapt to local conditions. Yet, policies and agents do not simply embed themselves locally, they also change local practices of gentrification. It would be a loss to urban theory to ignore commonalities, common trajectories and inter-local agents simply because particularities, difference and local agents are considered more worthy explanations of change. As Hackworth (2019) writes in his response this Forum: "The important point is figuring out which are actually local challenges or deviations from larger patterns and which are the residue of similar processes with different local wrapping."

One of the dominant forces in fifth-wave gentrification is finance; not simply capital, but financial capital, i.e. the concentration of capital in the hands of and controlled by financial institutions (cf. Hilferding, 1910). It is a period in which urban development is increasingly controlled by financial institutions. Rather than finance replacing the state, finance supplements the state in gentrification. Neither the state nor finance establish a monopoly over urban development, but they have become the dominant powers that give shape to it. Developers remain important, but "Financial actors can determine when cities grow ... as well as how and where they grow" (Weber, 2015: 39, emphasis in original). This does not imply other actors have no agency or that finance capital directs development in the same manner around the world, but it does mean we need to study the dominance of finance capital across cases to understand contemporary gentrification. 


\section{References}

AALBERS, M. B. (2008), The financialization of home and the mortgage market crisis. Competition \& Change 12(2), pp. 148-166.

AALBERS, M. B. (2011), The revanchist renewal of yesterday's City of Tomorrow, Antipode 43(5), pp. 1695-1724.

AALBERS, M. B. (2015), The Great Moderation, the Great Excess and the global housing crisis. International Journal of Housing Policy 15(1), pp. 43-60.

AALBERS, M.B. (2016), The Financialization of Housing: A Political Economy Approach. London: Routledge.

AALBERS, M. B. \& M. DEINEMA (2012), Placing prostitution: The spatial-sexual order of Amsterdam and its growth coalition. City 16(1-2), pp. 129-145.

ATKINSON, R. (2003) Domestication by cappuccino or a revenge on urban space? Control and empowerment in the management of public spaces. Urban Studies 40(9), pp. 1829-1843.

ATKINSON, R., S. PARKER \& R. BURROWS (2017), Elite formation, power and space in contemporary London. Theory, Culture \& Society 34(5-6), pp. 179-200.

BALL, M. (1994), The 1980s property boom. Environment \& Planning A 26, pp. 671-695.

BESWICK, J., G. ALEXANDRI, M. BYRNE, S. VIVES-MIRO, D. FIELDS, S. HODKINSON \& M. JANOSCHKA (2016). Speculating on London's housing future: The rise of global corporate landlords in 'post-crisis' urban landscapes. City 20(2), pp. 321-341.

BOYER, R. (2000), Is a finance-led growth regime a viable alternative to Fordism? A preliminary analysis. Economy and Society 29(1), pp. 111-145.

BYRNE, M. (2016), 'Asset Price Urbanism' and Financialization after the Crisis: Ireland's National Asset Management Agency. International Journal of Urban and Regional Research 40(1), pp. 31-45.

CALBET I ELIAS, L. (2017), Financialised rent gaps and public interest in Berlin's housing crisis. In: A. ALBET \& N. BENACH, eds., Gentrification as a Global Strategy, pp. 165-176. New York: Routledge.

CITY OF AMSTERDAM (2011), Project 1012. Voortgangsrapportage 2011. Amsterdam: Gemeente Amsterdam.

COAKLEY, J. (1994), The Integration of Property and Financial Markets. Environment and Planning A 26, pp. 99-112.

DAHLBERG, L. (2010), Cyber-libertarianism 2.0: A discourse theory/critical political economy examination. Cultural Politics 6(3), pp. 331-356.

DEINEMA, M. \& M. B. AALBERS (2012), A global red light city? Prostitution in Amsterdam as a real-and-imagined place. In M. DE WAARD, ed., Imagining Global Amsterdam: History, Culture, and Geography in a World City, pp. 273-287. Amsterdam: Amsterdam University Press.

DOUCET, B. (2014), A process of change and a changing process: Introduction to the special issues on contemporary gentrification. Tijdschrift voor Economische en Sociale Geografie 105(2), pp. 125-139.

FERNANDEZ, R. \& M. B. AALBERS (2016), Financialization and housing: Between globalization and Varieties of Capitalism. Competition and Change 20(2), pp. 71-88.

FERNANDEZ, R. \& M. B. AALBERS (2017), Capital Market Union and residential capitalism in Europe: Rescaling the housing-centred model of financialization. Finance and Society 3(1), pp. 32-50.

FERNANDEZ, R., A. HOFMAN \& M. B. AALBERS (2016), London and New York as a safe deposit box for the transnational wealth elite. Environment and Planning A 48(2), pp. 24432461.

FIELDS, D. (2015), Contesting the financialization of urban space: Community organizations and the struggle to preserve affordable rental housing in New York City. Journal of Urban Affairs 37(2), pp.144-165

FIELDS, D. (2017), Constructing a new asset class: Property-led financial accumulation after the crisis. Economic Geography 94(2), pp. 118-140.

FLORIDA, R. (2002) The Rise of the Creative Class: And How it's Transforming Work, Leisure, Community and Everyday Life. New York: Basic Books.

GANT, A. C. (2016), Holiday rentals: The new gentrification battlefront. Sociological Research Online 21(3): 10. DOI: 10.5153/sro.4071. 
GOTHAM, K. F. (2006), The secondary circuit of capital reconsidered: globalization and the US real estate sector. American Journal of Sociology 112(1), pp. 231-275.

GUIRONNET, A., K. ATTUYER \& L. HALBERT (2016), Building cities on financial assets: The financialisation of property markets and its implications for city governments in the Paris cityregion. Urban Studies 53(7), pp. 1442-1464.

HACKWORTH, J. (2019), Revisiting the changing state of gentrification. Tijdschrift voor Economische en Sociale Geografie 110: in press.

HACKWORTH, J. \& N. SMITH (2001), The changing state of gentrification. Tijdschrift voor Economische en Sociale Geografie 92(4), pp. 464-477.

HARVEY, D. (1989), From manageralism to entrepreneurialism: The transformation of urban governance in late capitalism. Geografiska Annaler, Series B: Human Geography 71(1), pp 317.

HAY, I. \& J. BEAVERSTOCK (2016), Handbook on Wealth and the Super-Rich. Cheltenham: Edward Elgar.

HENDRIKSE, R. (2015), The Long Arm of Finance: Exploring the Unlikely Financialization of Governments and Public Institutions. Amsterdam: Offpage.

HILFERDING, R. (1910), Finance Capital: A Study of the Latest Phase of Capitalist Development. Reprinted, London: Routledge \& Kegan Paul (1973).

HO, H. K. and R. ATKINSON (2017), Looking for big 'fry': The motives and methods of middleclass international property investors. Urban Studies, https://doi.org/10.1177/0042098017702826.

ING (2016), Airbnb heeft flink opwaarts effect of Amsterdamse huizenprijzen. URL: https://www.ing.nl/nieuws/nieuws_en_persberichten/2016/04/airbnb_heeft_flink_opwaarts_effe ct op_amsterdamse huizenprijzen.html (Accessed 14 July 2017).

LAMBEA LLOP, N. (2017), A policy approach to the impact of tourist dwellings in condominiums and neighbourhoods in Barcelona. Urban Research \& Practice 10(1), pp. 120-129.

LEE, D. (2016), How Airbnb Short-Term Rentals Exacerbate Los Angeles's Affordable Housing Crisis: Analysis and Policy Recommendations. Harvard Law \& Policy Review 10, pp. 229-254.

LEES, L. (2003) Super-gentrification: The case of Brooklyn Heights, New York City. Urban Studies 40, pp. 2487-2509.

LEES, L., T. SLATER \& E. WYLY (2008), Gentrification. New York: Routledge.

LEY, D. (1996), The New Middle Class and the Remaking of the Central City. Oxford: Oxford University Press.

LEY, D. (2017), Global China and the making of Vancouver's residential property market. International Journal of Housing Policy 17(1), pp. 15-34.

LOGAN, J. (1993), Cycles and trends in the globalization of real estate. In: P. KNOX, ed., The Restless Urban Landscape, pp. 33-44. Englewood Cliffs, NJ: Prentice Hall.

MCNEILL, D. (2016), Governing a city of unicorns: technology capital and the urban politics of San Francisco. Urban Geography 37(4), pp. 494-513.

MERMET, A.-C. (2017), Critical insights from the exploratory analysis of the 'Airbnb syndrome'in Reykjavík. In: M. GRAVARI-BARBAS \& S. GUINAND, eds., Tourism and Gentrification in Contemporary Metropolises: International Perspectives, pp. 52-74. New York: Routledge.

MERRIFIELD, A. (1993), The Canary Wharf debacle: From 'TINA'-there is no alternative-to 'THEMBA' - there must be an alternative. Environment and Planning A 25, pp. 1247-1265.

MOLLENKOPF, J. (1983), The Contested City. Princeton, NJ: Princeton University Press.

MOLOTCH, H. (1976), The city as a growth machine: Towards a political economy of place. American Journal of Sociology 82, pp. 309-330.

MOROZOV, E. (2013), To Save Everything, Click Here: The Folly of Technological Solutionism. New York: PublicAffairs.

PECK, J. (2012), Austerity urbanism: American cities under extreme economy. City 16(6), pp. $626-655$.

PECK, J. \& H. WHITESIDE (2016), Financializing Detroit. Economic Geography 92(3), pp. 235268.

ROGERS, D. \& S. Y. Koh (2017), The globalisation of real estate: The politics and practice of foreign real estate investment. International Journal of Housing Policy 17(1), pp. 1-14.

ROLNIK, R. (2013), Late neoliberalism: the financialization of homeownership and housing rights. International Journal of Urban and Regional Research 37(3), pp. 1058-1066. 
ROSE, D. (1984), Rethinking Gentrification: Beyond the Uneven Development of Marxist Urban Theory. Environment \& Planning D: Society \& Space 2(1), pp. 118-138.

ROUANET, H. \& L. Halbert (2015) Leveraging Finance Capital: Urban change and selfempowerment of real estate developers in India. Urban Studies 53(7), pp. 1401-1423.

SANS, A. A. \& A. QUAGLIERI (2016), Unravelling Airbnb: Urban perspectives from Barcelona. In: A. P. RUSSO \& G. RICHARDS, eds., Reinventing the Local in Tourism: Producing, Consuming and Negotiating Place, pp. 209-228. Bristol: Channel View.

SASSEN, S. (2014). Expulsions: Brutality and Complexity in the Global Economy. Cambridge, MA: Harvard University Press.

SEARLE, L. G. (2014), Conflict and commensuration: contested market making in India's private real estate development sector. International Journal of Urban and Regional Research 38(1), pp. 60-78.

SMITH, N. (1995), Gentrifying theory. Scottish Geographical Magazine 111(2), pp. 124-126.

SMITH, N. (2002), New globalism, new urbanism: Gentrification as global urban strategy. Antipode 34(3), 427-450.

TERESA, B. F. (2016), Managing fictitious capital: The legal geography of investment and political struggle in rental housing in New York City. Environment and Planning A 48(3), pp. 465-484.

VAN DER KEIJL, J. (2017), Stadscampings zien steeds vaker Airbnb-verhuurders. Het Parool (14 July), https://www.parool.nl/amsterdam/stadscampings-zien-steeds-vaker-airbnbverhuurders a4506254/.

VAN DER MEIJDEN, N. (2017), Amsterdams bedrijf wil eerste Airbnb-wijk ter wereld oprichten. Het Parool (12 June), https://www.parool.nl/amsterdam/amsterdams-bedrijf-wil-eerste-airbnbwijk-ter-wereld-oprichten a4500483/.

VAN GENT, W. \& BOTERMAN, W.R. (2019), Gentrification of the changing state. Tijdschrift voor Economische en Sociale Geografie 110: in press.

VAN LOON, J. \& M. B. AALBERS (2017), How Real Estate Became 'Just Another Asset Class': The Financialization of the Investment Strategies of Dutch Institutional Investors. European Planning Studies 25(2), pp. 221-240.

VAN LOON, J., S. OOSTERLYNCK \& M. B. AALBERS (2018), Governing urban development in the Low Countries: From managerialism to entrepreneurialism and financialization. Under review.

WALDRON, R. (2018), Capitalizing on the state: The political economy of Real Estate Investment Trusts and the 'resolution' of the crisis. Geoforum 90(2018), pp. 206-218.

WARD, K. (2006), 'Policies in Motion', Urban Management and State Restructuring: The TransLocal Expansion of Business Improvement Districts. International Journal of Urban and Regional Research 30(1), pp. 54-75.

WEBER, R. (2010), Selling City Futures: The Financialization of Urban Redevelopment Policy. Economic Geography 86(3), pp. 251-274.

WEBER, R. (2015), From Boom to Bubble: How Finance Built the New Chicago. Chicago: University of Chicago Press.

WEBBER, R. \& R. BURROWS (2016), "Life in an Alpha Territory: Discontinuity and conflict in an elite London 'village'. Urban Studies 53(15), pp. 1339-1354.

WEIKART, L. A. (2001), The Giuliani administration and the new public management in New York City. Urban Affairs Review 36(3), pp. 359-381.

WIJBURG, G. \& M. B. Aalbers (2017), The alternative financialization of the German housing market. Housing Studies 32(7), pp. 968-989.

WIJBURG, G., M.B. AALBERS \& S. HEEG (2018), The financialization of rental housing 2.0: Releasing housing into the privatized mainstream of capital accumulation. Antipode 50: https://doi.org/10.1111/anti.12382.

ZUKIN, S. (1982), Loft Living: Culture and Capital in Urban Change. Baltimore: Johns Hopkins University Press.

ZUKIN, S. (1995), The Cultures of Cities. Oxford: Blackwell. 